\title{
Incompatibility and Difference
}

— virodha and anyonyābhāvāvyabhicāritva-_

\section{Taiken KYūMA}

0 . In the third chapter of Nyāyabindu (NB) ${ }^{1)}$ Dharmakirti (ca.600-660) defines two kinds of incompatibility (virodha), i.e., 1) sahānavasthānavirodha ( $\mathrm{S}$, impossibility of co-existence in a certain place at the same time), 2) parasparaparihärasthitalakṣaṇavirodha ( $P$, mutual exclusion). These two are also found in Pramāṇavārttikasvavṛtti (PVSV) ${ }^{2)}$ and Pramāṇaviniścaya Svārthānumānam (Pvin II). ${ }^{3}$ ) While $S$ occurs between two opposed facts, e.g., the sensation of heat and that of coldness, P stands between a property and its negation, e.g. 'blue' and 'non-blue'. Vinitadeva, in his commentary on $\mathrm{NB}$, regards $\mathrm{S}$ as factual incompatibility (dnos po las gyur pa), and $\mathrm{P}$ as conceptual incompatibility (mtshan ñid las gyur pa $)^{4)}$. Dharmottara (c.750-810) also declares in his commentary on NB that $\mathrm{P}$ is conceptual incompatibility (lākșaṇikavirodha) ${ }^{5}$. Concerning $\mathrm{P}$, among these two, the following point is argued: can we say with fair certainty that not only a certain property and its negation, but also two mere different and affirmative properties, such as 'blue' and 'yellow', are incompatible? In this argument the conception of anyonyābhāvāvyabhicāritva (AN, the fact that the one does not deviate from the absence of the other) comes into question. The aim of this paper is to examine the character of $\mathrm{P}$, which is considered as conceptual incompatibility, by surveying how Dharmottara, Karṇakagomin (ca.800) and Jñānaśrimitra (ca. 980-1030) explain the conception of AN.

1. According to Dharmottara, 'blue' and 'non-blue' are directly incompatible by mutual exclusion ${ }^{6}$. But he also accepts incompatibility in the case of two mere different and affirmative properties, such as 'blue' and 'yellow', because AN exists between the two, even though 
mutual exclusion is lacking in them ${ }^{7)}$. Assuming it to be true, however, how can we distinguish incompatibility from mere difference? Let us suppose the following formula: "a sound is impermanent (anitya), because it is created (krtaka), as is a jar." If the concept of being created (krtakatva) and the concept of being impermanent (anityatva) should be incompatible, only because they are mutually different, this formula would be invalid, since the reason (hetu) in this formula, the concept of being created, would exist in dissimilar cases (vipakșa) and become the false reason called 'incompatible reason (viruddhahetu).' Of course, it is unlikely that Dharmottara passes over the distinction between incompatibility and mere difference. In fact, he recognizes no incompatibility between 'the concept of being speaker (vaktrtva)' and the concept of being omniscient (sarvajñatva)', because both concepts may exist in the same substratum ${ }^{8)}$. He also states that "substances are distinguished from one another by connecting with incompatible

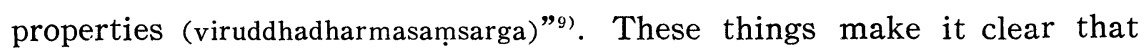
Dharmottara presupposes two different and affirmative properties which do not exist in the same substance when dealing with AN. In addition, Durvekamiśra suggests in his sub-commentary on NB that AN itself cannot cause incompatibility ${ }^{10)}$.

2. On the other hand, Karnakagomin insists in his commentary on PVSV that 'blue' and 'yellow are not incompatible, even if AN applies to this case, because both are the properties of substances and because it should not be concluded only from the absence of 'blue' that 'yellow' is always seen. ${ }^{11}$ He regards $\mathrm{P}$ as the negation of the identity between a property and its negation ${ }^{12}$ and it inevitably results in the exclusion of the other cases. But his too strict definition cannot cover the case of 'the concept of being permanent (nityatva)' and 'the concept of being causally efficient (arthakriyākāritva)', which belong to the key concepts in the proof of momentariness and are considered as incompatible.

3. Jñānaśrimitra takes up the concept of $\mathrm{AN}$ in his Kṣanabhangāahy- 
āya ${ }^{13)}$, and tries to distinguish incompatibility from AN in the context of causality. He synthesizes two kinds of incompatibility and defines incompatibility as "impossibility of co-existence of two things in the same substratum (dharmin: this word also means a certain place to which two opposed facts are related)" ${ }^{14)}$. If two facts cannot co-exist in the same place at the same time, $\mathrm{S}$ applies to this case, and when two properties or attributes cannot co-exist in the same substance or substratum, we can call it $\mathrm{P}$. He, who gives such a definition to incompatibility, asserts that $\mathrm{AN}$ is nothing but mere difference ${ }^{15}$. What $\mathrm{AN}$ can do is only to deny the identity between two different properties ${ }^{16)}$. The concept of being created is not identical with the concept of being impermanent because of $\mathrm{AN}$, nevertheless both are not incompatible, for they invariably exist in the same substance. Thus we can find nothing but mere difference between these two. On the contrary, 'the concept of being permanent' and 'the concept of being causally efficient' can never exist in the same substance and are consequently not only mutually different but also incompatible. According to Jñānaśrimitra, we can understand this incompatibility with the help of valid cognition, but it actually belongs to $\mathrm{P}^{17)}$. Turning now to the case of 'blue' and 'yellow', Jñānaśrimitra interprets them as merely different. Yet he also mentions the case in which they are incompatible, on condition that they don't exist in the same substance ${ }^{18}$. It follows from this example that there are two properties, which are compatible in some cases and incompatible in others.

4. Now we may say that Jñānaśrimitra gave a better explanation for the distinction between mere difference and incompatibility. If AN applies even to the case of two properties which are compatible in the same substance, incompatibility cannot result only from AN. Moreover, if we take account of the fact that conceptual incompatibility is established in relation to the substance, it seems reasonable to conclude that $\mathrm{P}$, as conceptual incompatibility, is never irrelevant to facts. And this conclusion will be supported by the well-known viewpoint in Bud- 
dhist pramāṇa tradition that an attribute cannot exist independently of its substratum.

1) Dharmakīrti: Nyāyabindu (NB) in Paṇdita Durvekamiśra's Dharmottarapradīpa (DhP, it also contains Dharmottara's commentary and Durvekamiśra's subcommentary on NB), ed. by D. Marvania, Patna 1971. pp. 198-203.

2) Dharmakīrti: Pramāṇavārttikasvavṛtti (PVSV). Raniero Gnoli, The Pramānavārttikam of Dharmakïrti, the first chapter with the auto-commentary, Text and Critical Notes, Roma 1960. p. 5, 13-15.

3) Dharmakīrti: Pramāṇaviniścaya Svārthānumānam (Pvin II ). Ernst Steinkellner, Dharmakīrti's Pramānaviniścayaḥ, zweites Kapitel: Svārthānumānam. Teil I, Tibetischer Text und Sanskrittexte. Wien 1973. p. 13*,3-7.

4) Vinītadeva: Nyāyabinduțīkā (rig paḥi thigs pahi rgya cher ḥgrel pa) P. No. 5729, D. No. 4230 , We $26 \mathrm{~b}-4$.

5) $\mathrm{DhP}$ p. 206, 1.

6) DhP p. 204, 2.

7) DhP pp. 203, 14-204, 3.

8) DhP p. 280, 1-6.

9) DhP p. 25, 1-2. cf. PVSV p. 20, 21-22.

10) DhP p. 204, 27-28.

11) Karṇakagomin: Pramānavārttikasvavṛttiṭikā (PVSVṭ) ācārya-Dharmakīrteh Pramānavārttikam (svārthānumānaparicchedaḥ) svopajñavṛttyā Karṇakagomiviracitayā tațtịkayā ca sahitam, ed. by R. Sānnkṛtyāyana, Allahabad 1943 (rep. Kyoto 1982). pp. 36, 29-37. 5.

12) PVSVṭ p. 36, 27-29.

13) Jñānaśrīmitra: Kṣaṇabhañgādhyāya. Jñānaśrīmitranivandhāvalị̣ (JN) ed. by A. Thakur, Patna 1987. pp. 1-159.

14) JN p. 37-19.

15) $\mathrm{JN}$ p. $37,21-22$, p. $38,18-19$.

16) JN pp. $38,24-39.1$.

17) JN p. 65, 6-8. Here Jñānaśrīmitra quotes a part of PV $\mathbb{N} .279$.

18) $\mathrm{JN}$ p. $37,22-23$.

〈Key Words〉 virodha, anyonyābhāvāvyabhicāritva, Dharmottara, Karṇakagomin, Jñānaśrīmitra

(Graduate Student, Tōkyō University) 